\title{
KEMAMPUAN SOSIAL ANAK KELOMPOK BERMAIN DITINJAU DARI POLA PENGASUHAN ORANGTUA
}

\author{
Isabella Hasiana \\ Program Studi Pendidikan Guru Anak Usia Dini, Fakultas Keguruan dan \\ Ilmu Pendidikan, Universitas PGRI Adi Buana Surabaya \\ Email: isabella@unipasby.ac.id
}

\begin{abstract}
This research can be informed by neightborsaround the residence that there were children who were not able to socialize with their peers. The aim of this study was to find out the social abilities of the children in the play group in terms of the pattern of Permissive Parenting. The subjects used in this study were two children with the same parenting pattern. (1) This research method uses descriptive Qualitative, so that it can explain in detail how the Socialization capabilities carried out by group children play with the pattern of Permissive Parenting from the Tuanua people. Observation and interview are data retrieval carried out in this study, (2) The results of this study get a new finding, where the first subject has not had a good development at this time, the habit of Permissive Parenting makes it difficult for children to Socialize and tend to be spoiled by their parents. While the second subject is equally nurtured with Permissive Parenting patterns, but the second subject has been able to achieve the desired Socialization according to the level of his age, the difference is in habituation to the second subject even though he is spoiled by his parents because of the first child but he is parents because of the first child but he is getting used to knowing which is good and bad so that children are able to reach their Social sense easily.
\end{abstract}

Keywords : Parenting, Social Development, Early Childhood.

\section{PENDAHULUAN}

Pendidikan bagi anak usia dini merupakan salah satu bentuk penyelenggaraan pendidikan yang menitikberatkan pada peletakkan dasar ke arah pertumbuhan dan enam perkembangan yakni; agama dan moral, fisik motorik, kognitif, bahasa, sosial-emosional, dan seni, sesuai dengan keunikan dan tahapan perkembangan yang sesuai dengan kelompok anak usia dini dan tercantum dalam Permendikbud 137 Tahun 2014 tentang Standart Nasional Pendidikan Anak Usia Dini (PAUD) (https://id.m.wikipedia.org.

Masa usia dini merupakan masa emas (golden age) yang hanya datang sekali seumur hidup dan tidak dapat diulang. Pada masa ini anak berada pada periode sensitif (sensitive periods) dan mudah untuk menerima berbagai stimulus dari lingkungannya. Sekitar 50\% kecerdasan orang dewasa sudah terjadi ketika anak berusia 4 tahun, kemudian terjadi peningkatan $30 \%$ pada usia 8 tahun, dan $20 \%$ sisanya pada pertengahan atau akhir dewasa kedua. Ini berarti perkembangan yang terjadi pada usia 0-4 tahun sama besarnya dengan perkembangan yang terjadi pada usia 4-18 tahun. Oleh sebab itu, pelaksanaan dan penyelenggaraan pendidikan anak usia dini (PAUD) sangatlah penting dan hal itu membawa dampak terhadap kehidupan anak selanjutnya (Ardy, 2014:7).

Kelompok Bermain (KB) adalah salah satu bentuk satuan PAUD jalur pendidikan nonformal yang menyelenggarakan program bagi anak usia 2 hingga 4 tahun, untuk membantu pertumbuhan dan perkembangan anak agar kelak siap memasuki pendidikan yang lebih lanjut. Selain itu, kelompok bermain juga dapat melayani anak hingga usia 6 tahun, jika dilokasi yang sama belum tersedia layanan TK/RA (Helmawati, 2012:56).

Pendidikan anak usia dini adalah suatu upaya pembinaan yang ditujukan kepada anak sejak lahir sampai usia enam tahun yang dilakukan melalui pemberian rangsangan pendidikan untuk membantu pertumbuhan dan perkembangan jasmani dan rohani agar anak 
memiliki kesiapan lebih lanjut (UU No. 20 Tahun 2003 Tentang Sisdiknas). Keberadaan PAUD formal dan nonformal ini jika dilihat dari posisi jalur pendidikan tentunya membantu orang tua dalam memberikan rangsangan pendidikan untuk membantu pertumbuhan dan perkembangan anak akan pendidikan di luar rumah, agar anak siap saat memasuki pendidikan dasar.

PAUD sendiri bertujuan untuk membentuk anak Indonesia yang berkualitas, yaitu anak yang tumbuh dan berkembang sesuai dengan tingkat perkembangannya sehingga memiliki kesiapan yang optimal di dalam memasuki pendidikan dasar serta mengarungi kehidupan pada masa dewasa. Juga untuk membantu menyiapkan anak mencapai kesiapan belajar (akademik) disekolah, sehingga dapat mengurangi usia putus sekolah dan mampu bersaing secara sehat di jenjang pendidikan berikutnya.

Manfaat PAUD tidak hanya untuk aspek kognitif anak yang dilatih, namun juga aspek-aspek lainnya seperti; motorik halus, motorik kasar, seni, pembiasaan moral yang berkarakter, kemampuan sosial, dan bahasa. Pada tahap ini anak harus diperkenalkan dengan nilai-nilai yang berlaku dimasyarakat, seperti; nilai agama, budaya, adat istiadat agar anak bisa diterima oleh lingkungan disekitarnya.

Berdasarkan observasi awal yang dilakukan, penulis menemukan sebuah fakta bahwa ada anak yang kesulitan dalam bersosialisasi dengan lingkungannya. Sedangkan hasil observasi di lapangan adalah anak tersebut kurang mendapatkan stimulus dan pembiasaan dari kedua orang tuanya karena sibuk bekerja.

Salah satu masalah untuk menggapai perkembangan anak usia dini sesuai dengan tingkat usianya, yaitu kedua orang tua yang sibuk bekerja dan menitipkan anaknya agar diasuh oleh neneknya. Terlebih lagi ia adalah cucu pertama dan pasti mendapatkan segalanya dari neneknya, cenderung dimanja dan dituruti keinginannya. Hal seperti ini dapat mengakibatkan anak menjadi anak yang kurang memiliki pendirian dan suka bergantung pada orang lain, hal ini dapat dilihat ketika anak terlalu di turuti segala keinginannya dengan neneknya sedangkan ibu atau orang tua nya membiasakan anak untuk mengambil yang dia inginkan sendiri tanpa menyuruh orang lain.
Misalnya orang tua membiasakannya dengan pola asuh demokratis yang cenderung mendorong anak untuk terbuka, bertanggung jawab dan mandiri dengan pendekatan yang hangat, lebih memprioritaskan kepentingan anak dan cenderung memberikan kebebasan pada anak untuk memilih tetapi tetap dalam pengawasan orang tua. Sedangkan nenek cenderung lebih membiasakan anak dengan pola asuh permisif yang cenderung memberikan pengawasan yang sangat longgar dan kebebasan kepada anak, tidak ada bimbingan dan pengarahan dari nenek. Kontrol dan perhatian nenek kurang dan suka memanjakan cucu nya dan menuruti semua keinginannya.

Ada beberapa dampak yang terjadi kepada anak jika Ibu atau pengasuh tidak melakukan stimulasi yang rutin kepada anak, yaitu anak akan belum mampu dalam hal bersosialisasi dengan teman sebayanya. Hal ini akan berdampak tidak baik untuk masa depan anak, dan akan menimbulkan rasa kurang mandiri pada diri anak yang disebabkan oleh pembiasaan sejak kecil selalu dimanjakan oleh nenek nya. Dan dikarenakan juga waktu yang sedikit dari orang tua untuk anak tersebut. Dengan kebiasaan yang seperti ini, apabila terus berlangsung akan membuat anak kesulitan menjadi pribadi yang mandiri, sulit dalam mengembangkan kemampuannya, selalu bergantung pada orang lain, tidak menyukai kekalahan, sulit berteman, mudah menyerah ketika dihadapkan pada masalah dan rintangan, lebih tertarik pada cara instan, berdampak kurang baik pada karakter anak setelah dewasa, kurang menghargai orang tuanya kelak.

Dari paparan di atas, penelitian ini ingin menjawab permasalahan, (1) Bagaimana pola asuh permisif dalam kemampuan bersosialisasi anak usia dini, (2) Apa saja faktor-faktor yang mempengaruhi kemampuan bersosialisasi anak usia dini dengan pola asuh permisif. Hasil dari penelitian ini diharapkan dapat bermanfaat dalam meningkatkan pengetahuan dan wawasan orang tua tentang pola asuh permisif dan dampaknya bagi kemampuan bersosialisasi anak.

Dalam artikel ini, konsep pola asuh dan kemampuan sosial anak usia dini dipilih sebagai dasar kajian karena kedua konsep tersebut sesuai dengan gambaran umum kemampuan sosialisasi anak yang ditinjau dari pola pengasuhan permisif. Melalui kedua konsep tersebut dapat diketahui makna sosial dan pola pengasuhan permisif beserta dampaknya bagi anak.

Istilah Pola asuh dalam pandangan Gunarsa (Solikha, 2016:9), yaitu sebagai gambaran yang dipakai orang tua untuk mengasuh, merawat, 
menjaga dan mendidik anak. Menurut Kamus Besar Bahasa Indonesia, pola berarti corak, model, sistem, cara kerja, bentuk (struktur) yang tetap. Sedangkan kata asuh memiliki arti menjaga (merawat dan mendidik) anak kecil, membimbing (membantu, melatih dan sebagainya) dan memimpin (mengepalai dan menyelenggarakan) satu badan atau lembaga. Ditambah menurut Casmini (Solikha, 2016:9), Pola asuh orang tua adalah bagaimana orang tua memperlakukan anak, mendidik, membimbing, dan mendisiplinkan anak dalam mencapai proses kedewasaan hingga pada upaya pembentukkan norma-norma yang diharapkan masyarakat pada umumnya.

Pada bagian ini, kita akan lebih berkonsentrasi pada salah satu kunci yaitu "Pola Asuh Permisif", Perilaku orang tua yang permisif merupakan kebalikan dari perilaku orang tua yang protektif. Orang tua yang berperilaku permisif cenderung terlalu melepas anak dengan cara membebaskan anak melakukan segala keinginannya. Selain berlandaskan pada keyakinan bahwa anaknya sudah cukup besar, orang tua seperti ini cenderung tidak mampu mendisiplinkan anaknya. Hal yang perlu di khawatirkan dari anak yang diasuh dengan pola asuh permisif adalah anak tumbuh menjadi orang yang selalu menuntut agar segala kemauannya dituruti. Selain itu, anak seperti ini cenderung memiliki sifat pembangkang. Pada umumnya pola asuh permisif ini menggunakan komunikasi satu arah (one way communication) karena meskipun orang tua memiliki kekuasaan penuh dalam keluarga terutama terhadap anak tetapi anak memutuskan apa-apa yang diinginkannya sendiri baik orang tua setuju ataupun tidak. Pola asuh ini bersifat children centered maksudnya adalah bahwa segala aturan dan ketetapan keluarga berada di tangan anak.

Pola asuh permisif ini kebalikan dari pola asuh otoriter. Dalam pola asuh otoriter, semua keinginan orang tua harus diikuti baik anak setuju ataupun tidak, sedangkan dalam pola asuh permisif orang tua harus mengikuti keinginan anak baik orang tua setuju ataupun tidak. Strategi komunikasi dalam pola asuh ini yaitu bersifat win-lose solution. Artinya, apa yang diinginkan anak selalu dituruti dan diperbolehkan oleh orang tua. Orang tua mengikuti segala kemauan anaknya. Anak cenderung menjadi bertindak semena-mena, anak bebas melakukan apa saja yang diinginkannya tanpa memandang bahwa itu sesuai dengan nilainilai atau norma-norma yang berlaku atau tidak. Sisi negatif dari pola asuh ini adalah anak kurang disiplin dengan aturan-aturan sosial yang berlaku. Namun sisi positifnya, jika anak menggunakannya dengan tanggung jawab maka anak tersebut akan menjadi seorang yang mandiri, kreatif, inisiatif, dan mampu mewujudkan aktualisasi dirinya di masyarakat (Helmawati, 2014:138).

Dari uraian di atas dapat disimpulkan bahwa Orang tua tipe permisif lebih memperhatikan aktivitas diri mereka sendiri dan tidak terlibat dengan aktivitas anak-anaknya. Mereka tidak tahu di mana anak-anak mereka berada, apa yang sedang dilakukan, dan siapa teman-temannya saat diluar rumah. Mereka tidak tertarik pada kejadiankejadian di sekolah anak, jarang bercakap-cakap dengan anak-anaknya, dan tidak memperdulikan pendapat anak-anaknya.

Konsep lain setelah pola pengasuhan permisif yaitu "Sosial", Kata sosial berkenaan dengan hubungan antara seorang individu dengan individu lainnya. Howard Gardner (Ardy, 2014:18) menyebut hubungan yang demikian dengan istilah hubungan interpersonal. Hubungan interpersonal dalam kehidupan sehari-hari manusia tidak dapat dihindarkan. Bahkan, tanpa adanya hubungan tersebut manusia sudah dipastikan tidak akan bisa bertahan hidup.

Perkembangan sosial merupakan pencapaian kematangan dalam hubungan sosial. Dapat juga diartikan sebagai proses belajar untuk menyesuaikan diri terhadap norma-norma, kelompok, moral, dan tradisi meleburkan diri menjadi suatu kesatuan yang saling berkomunikasi dan bekerja sama. Anak dilahirkan belum bersifat sosial. Dalam arti, anak belum memiliki kemampuan untuk bergaul dengan orang lain. Untuk mencapai kematangan sosial, anak harus belajar tentang cara-cara menyesuaikan diri dengan orang lain di lingkungannya. Perkembangan sosial juga dapat diartikan sebagai proses dimana anak mengembangkan keterampilan interpersonalnya, belajar menjalin persahabatan, meningkatkan pemahamannya tentang orang diluar dirinya, dan juga belajar penalaran moral dan perilaku. Perkembangan sosial merupakan perkembangan hubungan atau interaksi dengan orang tua, dan teman sebaya. Perkebangan sosial anak sangat dipengaruhi oleh proses perlakuan atau bimbingan orang tua terhadap anak dalam mengenalkan berbagai aspek kehidupan sosial.

\section{METODE PENELITIAN}

Metode yang digunakan dalam penelitian ini adalah metode pendekatan deskripsi kualitatif. Artinya, data yang dikumpulkan bukan berupa angka-angka melainkan data tersebut berasal dari naskah wawancara dan laporan observasi. Fokus utama pendekatan penelitian ini adalah melakukan studi kehidupan sehari-hari anak. Terutama dalam 
institusi dimana anak mendapatkan pengasuhan dan pembelajaran yaitu di keluarga. Penelitian ini menggunakan instrument penelitian berupa pedoman wawancara dan observasi, sedangkan teknik pengumpulan data melalui observasi dan wawancara. Data dikumpulkan dari sumber data langsung, agar dapat diketahui kemampuan anak secara alami. subjek dalam penelitian ini adalah anak kelompok bermain B yang berusia $3-4$ tahun. Anak kelompok bermain B yang memiliki rentang usia $3-4$ tahun tidak hanya disekolah, namun penulis menggunakan anak yang masih belum sekolah yang rentang usianya $3-4$ tahun seperti kualifikasi usia untuk anak kelompok bermain B. Penemuan subjek dilakukan dengan cara purposive sampling. Menurut (Sugiyono, 2015: 218), Purposive Sampling adalah teknik pengambilan sampel sumber data dengan pertimbangan tertentu. Pertimbangan tertentu ini, misalnya orang tersebut dianggap paling tahu tentang apa yang kita harapkan, atau mungkin dia sebagai penguasa sehingga akan memudahkan peneliti penjelajahi obyek/situasi sosial yang diteliti. Pengambilan sampel ini disesuaikan dengan kriteria yang dibutuhkan untuk penelitian. Analisa data dalam penelitian ini yaitu model analisis data berlangsung atau mengalir (flow model analysis). Untuk meyakinkan bahwa data dalam penelitian ini Valid atau tidak, maka di lakukan tiga hal, yakni, Validasi Komunikatif, Validasi Ekologi, Validasi Argumentasi.

\section{HASIL DAN PEMBAHASAN}

Subjek dalam penelitian ini sejumlah dua orang yang masing-masing memiliki karakteristik yang berbeda pula. Karakteristik subjek 1 yaitu anak yang berusia $3-4$ tahun yang diasuh oleh nenek di rumah. Lebih tepatnya subjek 1 berusia 3 tahun lebih 3 bulan. Subjek 1 berinisialkan ZZ dan Ibu dari subjek 1 berinisialkan IZ. Subjek 1 tinggal bersama dengan Ibu, Ayah, dan Nenek. Namun kedua orang tua dari subjek 1 lebih banyak menghabiskan waktunya untuk bekerja, oleh sebab itu subjek 1 lebih banyak menghabiskan waktu bersama dengan Neneknya. Namun, hal ini tidak menyebabkan ZZ lebih dekat dengan Neneknya, ZZ tetap cenderung dekat dengan Ibu dan Ayahnya. ZZ termasuk anak yang pendiam, tidak banyak bicara, dan sulit untuk berteman dengan lingkungannya. $\mathrm{ZZ}$ adalah anak satu-satunya di rumah tersebut. Sehingga dia tidak memiliki saudara untuk di ajak berkomunikasi atau bermain. Meski ada Neneknya, namun ZZ jarang sekali di ajak bermain. Keseharian ZZ di rumah adalah mandi, makan, melihat televisi dan tidur. Bermain pun dia hanya bermain sendiri. ZZ pun jarang sekali diajak keluar rumah oleh Neneknya. Mungkin hal itu juga yang menyebabkan ZZ kurang dalam bersosialisasi.

Sedangkan karakteristik subjek 2 adalah anak usia 3 - 4 tahun yang di asuh oleh Ibu dengan pengasuhan permisif. Lebih tepatnya subjek 2 berusia 3 tahun lebih 11 bulan. Subjek 2 ini berinisialkan LL dan Ibu dari subjek 2 berinisialkan IL. Subjek ke-2 tinggal bersama dengan Ibu, Ayah, Nenek, Kakek, dan Saudara sepupunya. Ibu IL kurang dalam memperhatikan LL, hal ini disebabkan karena Ibu IL yang merasa bahwa anaknya telah memiliki banyak teman dan banyak yang bisa menjaganya. LL merupakan anak yang ceria, suka berteman, dan tidak pilih-pilih dalam berteman. LL suka sekali menanyakan sesuatu hal yang belum di ketahuinya. LL adalah anak yang sangat interaktif dengan teman sebayanya dan juga dengan orang dewasa yang ia kenal. Semua orang di ajak untuk bermain bersama dengan LL. Jika Ibu IL sedang sibuk, maka LL akan ditemani dan diawasi oleh Nenek atau Kakeknya. Keadaan ini yang membuat LL lebih ceria, komunikatif, dan selalu suka bertanya apa yang belum ia pahami dan mengerti.

Menurut Standart Tingkat Pencapaian Perkembangan Anak Usia $3-4$ tahun, Perkembangan sosial anak meliputi; (a) Mengikuti aktivitas dalam suatu kegiatan besar (misal, piknik), (b) Meniru apa yang dilakukan oleh orang dewasa, (c) Bereaksi terhadap hal-hal yang tidak benar (marah bila diganggu), (d) Mengatakan perasaan secara verbal, (e) Mulai bisa melakukan buang air kecil sendiri tanpa bantuan, (f) Bersabar menunggu giliran (antri), (g) Mulai menunjukkan sikap toleran sehingga dapat bekerja dalam kelompok, (h) Mulai menghargai orang lain, (i) Mulai menunjukkan ekspresi menyesal ketika melakukan kesalahan, (j) Membangun kerjasama, (k) Memahami adanya perbedaan perasaan (teman takut, saya tidak), (l) Meminjam dan meminjamkan mainan.

Pada subjek pertama ZZ, tingkat kemampuan sosialnya belum berkembang. Hal ini dikarenakan masih terdapat beberapa hal yang masih belum ZZ kembangkan. Seperti; kurang bisanya ZZ dalam membangun kerja sama dengan teman, belum mampu menunjukkan sikap toleran dalam kelompok, juga belum mampu dalam buang air kecil sendiri tanpa bantuan. Dari Standart Tingkat Pencapaian Perkembangan Anak usia $3-4$ tahun, terdapat banyak hal yang belum dapat dicapai oleh ZZ. Hal ini mungkin disebabkan karena kurangnya perhatian dan pembiasaan dari orang tua maupun pengasuh. Pola asuh orang tua permisif yang di berikan orang tua kepada anak dari kedua subjek, tingkatan ke permisifnya berbedabeda. Pada subjek pertama ZZ, yang diterapkan 
orang tua adalah permisif tanpa penjelasan sedikitpun dari orang tua. Yang penting anak merasa bahagia dan senang. Subjek pertama ZZ memiliki waktu yang lama dalam hal menyesuaikan diri terhadap lingkungan. Yang terlihat dalam kegiatan sehari-hari, Subjek pertama ZZ masih belum bisa membaur dan nyaman dalam kelompok dan terkadang hanya nyaman terhadap lingkungan keluarga dekatnya saja. ZZ terlihat masih malumalu dan sulit sekali dalam berteman. Hal ini mungkin disebabkan oleh kurang diberikannya pengertian sejak kecil oleh orang tua maupun pengasuhnya. Sehingga ZZ berbuat sesuai dengan apa yang dia inginkan tanpa mengetahui benar dan tidak benarnya yang diperbuat.

Karakteristik perkembangan sosial anak usia $3-4$ tahun adalah anak memiliki hubungan pertemanan yang mulai meningkat. Peningkatan tersebut terjadi seiring dengan berkembangnya aspek moralitas pada anak. Anak mulai mengenali mana yang benar dan mana yang tidak benar. Anak mulai memahami tentang berbohong dan mengapa ia tidak boleh berbohong, serta memahami tentang kesalahan (mengapa berbuat salah dan apa yang harus dilakukan untuk kesalahannya). Perkembangan aspek moralitas tersebut juga menjadikan anak dapat bermain bersama dengan teman-temannya (bermain kooperatif). (Wiyani, 2014:34). Namun ZZ masih belum mampu dalam membedakan mana sikapnya yang tidak benar dan mana yang benar. Karena semua yang dilakukan oleh ZZ baik atau buruknya, tidak pernah di berikan masukan oleh orang tua maupun pengasuhnya. Dibiarkan begitu saja sehingga membuat $\mathrm{ZZ}$ terbiasa merasa yang dia lakukan benar. Aspek pengasuhan memang wajib diterapkan dalam pembentukan sosialisasi anak. Dari segi komunikasi, ZZ hanya mau berkomunikasi dan berinteraksi dengan orang tua dan keluarga terdekatnya yang sering di temuinya saja. Seperti Ayah, ibu, nenek. Ketika ada saudara sepupunya yang main kerumah ZZ, ZZ membutuhkan waktu untuk mengenalnya ulang. Begitupun dengan lingkungannya yang hampir tidak pernah ia lihat. Pasti butuh banyak waktu untuk mendekatkan ZZ dengan lingkungannya.

Sedangkan pada subjek kedua LL, orang tuanya menerapkan pola asuh permisif namun orang tua masih menjelaskan tentang hal-hal yang dilakukan baik atau tidak baik. Sehingga membuat anak mengerti tentang hal-hal yang benar maupun tidak benar. Perkembangan sosial anak dapat dilihat dari kemampuan anak bersosialisasi dengan teman sebayanya sebagaimana yang dikemukakan oleh Santrock (dalam Solikha, 2016:49). Kemampuan bersosialisasi dengan teman sebaya juga termasuk sikap anak terhadap temannya. Pada usia dini, anak semakin intens dalam melakukan hubungan sosialisasi dengan temannya. Pada subjek kedua LL sudah terlihat mampu dalam berdaptasi dengan lingkungan sekitar rumahnya, namun tergantung Mood LL juga, jika mood LL baik ia akan cepat dalam beradaptasi dengan lingkungannya, namun jika tidak maka sebaliknya. Sedangkan dalam hal membantu temannya, subjek kedua LL terlihat sudah mampu, dan tidak pernah menolak ketika dimintai tolong oleh temannya. Aspek pengasuhan memang wajib diterapkan dalam pembentukan sosialisasi anak. Dari segi komunikasi, LL lebih mampu mengungkapkan apa yang dia inginkan dan apa yang dia rasakan, cenderung melakukan apapun sesuka hatinya. Terkadang ia meminta ijin kepada ibu IL atau neneknya untuk memastikan yang dilakukannya benar maupun tidak benar.

Dari kedua subjek tersebut dapat dilihat, kemajuan sosialisasi dapat dibentuk baik atau buruk dari perilaku orang tua serta kerja sama dengan orang terdekat anak mereka. Salah satu saja, tidak berkomitmen untuk membentuk sosialisasi anak dalam hal anak mau berbagi mainan dengan teman lainnya, maka selama itu pula sosialisasi tersebut tidak dapat tercapai. Maka dari itu pengasuhan anak amat sangat berperan penuh dalam terbentuknya sosialisasi anak itu sendiri. Juga dalam hal memperhatikan perkembangan anak secara terus menerus, anak usia dini masih membutuhkan pantauan dari orang tuanya. Dan sering di stimulasi dalam berkomunikasi, baik dengan teman sebayanya maupun dengan orang dewasa lainnya.

Selain itu, meski anak dibiasakan dengan pola pengasuhan permisif namun akan lebih baik apa bila pengasuhan permisif tersebut seraya diberikan masukan sedikit demi sedikit, diberi pengertian sederhana tentang hal-hal sederhana. Agar anak lebih mampu dalam membedakan mana yang benar dan mana yang tidak benar.

\section{SIMPULAN}

Dalam penelitian ini dapat disimpulkan bahwa perkembangan sosial anak sangat dipengaruhi oleh proses perlakuan atau bimbingan orang tua terhadap anak dalam berbagai aspek kehidupan sosial atau norma-norma kehidupan bermasyarakat. Dalam hal ini yang dimaksud adalah pola pengasuhan. Pola pengasuhan dapat mempengaruhi perkembangan anak. Beberapa pengaruh yang timbul dari adanya pola pengasuhan permisif terhadap kemampuan bersosialisasi anak yaitu: (1) Pola asuh permisif dalam kemampuan bersosialisasi pada subjek pertama $\mathrm{ZZ}$ dan subjek kedua LL tingkatan permisifnya berbeda, 
maksudnya yaitu pada subjek pertama ZZ lebih cenderung memanjakan dan tidak menegur apabila melakukan kesalahan. Sedangkan pada subjek kedua LL, tetap dimanjakan namun ketika melakukan suatu kesalahan akan ada teguran dan arahan yang baik. Hal seperti ini yang membuat anak menjadi terbiasa melakukan sesuatu yang baik dan benar maupun sebaliknya. Begitupun dalam hal bersosialisasi, jika anak tidak dirangsang untuk bersosialisasi sejak dini maka anak tersebut tidak akan belajar untuk dapat diterima di lingkungan sekitarnya. seperti yang terjadi pada ZZ yang kurang dibiasakan untuk bersosial dengan lingkungannya sehingga membuat $\mathrm{ZZ}$ sulit untuk berteman dan bersosial dengan lingkungan sekitarnya. Lain dengan LL yang sangat mudah bergaul dan beradaptasi dengan lingkungannya karena pembiasaan sejak dini, (2) Faktor-faktor yang mempengaruhi kemampuan bersosialisasi anak dengan pola asuh permisif, yaitu; Keterlibatan orang tua dalam mengasuh anak dan Hubungan dalam keluarga yang harmonis.

\section{DAFTAR PUSTAKA}

Ardy, Wiyani Novan. 2014. Mengelola dan

mengembangkan kecerdasan sosial dan emosi anak usia dini. Yogyakarta: ArRuzz Media.

Helmawati. 2015. Mengenal dan Memahami

PAUD. Bandung: PT Remaja Rosdakarya.

Solikha, Sofia. 2016. Pengaruh Pola Asuh Orang

Tua Otoriter Terhadap Kemampuan Sosialisasi Anak Kelompok B TK Bakat Remaja Surabaya. Surabaya: Universitas PGRI Adi Buana.

Sugiyono. 2015. Metode Penelitian Kuantitatif,

Kualitatif, dan R\&D. Bandung: Alfabeta. 